\title{
Article \\ Production of Biochar from Vine Pruning: Waste Recovery in the Wine Industry
}

\author{
Leonel J. R. Nunes ${ }^{1, *(\mathbb{D}}$, Abel M. Rodrigues ${ }^{2,3}$, João C. O. Matias ${ }^{4,5}\left(\mathbb{D}\right.$, Ana I. Ferraz ${ }^{1}\left(\mathbb{D}\right.$ and Ana C. Rodrigues ${ }^{1}(\mathbb{D}$ \\ 1 PROMETHEUS, Unidade de Investigação em Materiais, Energia e Ambiente para a Sustentabilidade, \\ Escola Superior Agrária, Instituto Politécnico de Viana do Castelo, Rua da Escola Industrial e Comercial de \\ Nun'Alvares, 4900-347 Viana do Castelo, Portugal; aferraz@esa.ipvc.pt (A.I.F.); \\ acrodrigues@esa.ipvc.pt (A.C.R.) \\ 2 INIAV-Instituto Nacional de Investigação Agrícola e Veterinária, Av. da República, \\ Quinta do Marquês (Edifício Sede), 2780-157 Oeiras, Portugal; abel.rodrigues@iniav.pt \\ 3 MARETEC-Marine, Environment \& Technology Center, Secção de Ambiente e Energia, \\ Departamento de Engenharia Mecânica, Instituto Superior Técnico, Av. Rovisco Pais N. ${ }^{\circ} 1$, \\ 1049-001 Lisboa, Portugal \\ 4 GOVCOPP, Unidade de Investigação em Governança, Competitividade e Políticas Públicas, \\ Universidade de Aveiro, Campus Universitário de Santiago, 3810-193 Aveiro, Portugal; jmatias@ua.pt \\ 5 DEGEIT, Departamento de Economia, Gestão, Engenharia Industrial e Turismo, Universidade de Aveiro, \\ Campus Universitário de Santiago, 3810-193 Aveiro, Portugal \\ * Correspondence: leonelnunes@esa.ipvc.pt
}

check for updates

Citation: Nunes, L.J.R.; Rodrigues, A.M.; Matias, J.C.O.; Ferraz, A.I.; Rodrigues, A.C. Production of Biochar from Vine Pruning: Waste Recovery in the Wine Industry. Agriculture 2021, 11, 489. https:// doi.org/10.3390/agriculture11060489

Academic Editors: Marco Lauteri,

Tommaso La Mantia and

Anastasia Pantera

Received: 3 April 2021

Accepted: 24 May 2021

Published: 25 May 2021

Publisher's Note: MDPI stays neutral with regard to jurisdictional claims in published maps and institutional affiliations.

Copyright: (c) 2021 by the authors. Licensee MDPI, Basel, Switzerland. This article is an open access article distributed under the terms and conditions of the Creative Commons Attribution (CC BY) license (https:/ / creativecommons.org/licenses/by/ $4.0 /)$.

\begin{abstract}
The production of residual biomass, such as vine pruning, presents environmental problems since its elimination is usually carried out through the uncontrolled burning of the remaining materials and with the emission of greenhouse gases without any counterpart. The use of these residues to produce biochar presents several advantages. In addition to the more common energy recovery, other conversion ways allowing new uses, such as soil amendment and carbon sequestration, can be analyzed as options as well. In the present study, vine pruning biomasses are characterized to evaluate the behavior of the different constituents. Then, the different possible applications are discussed. It is concluded that materials resulting from the pruning of vineyards have excellent characteristics for energy recovery, with an increment of more than $50 \%$ in the heating value and almost $60 \%$ in the carbon content when carbonized. This recovery procedure contributes to creating new value chains for residual materials to promote sustainable practices in the wine sector.
\end{abstract}

Keywords: biochar; vine pruning; biomass waste; circular economy; sustainability

\section{Introduction}

The use of biomass as a form of energy acquired a recent interest, despite being the oldest form of energy, accompanying developing mankind since the discovery of fire [1,2]. Obviously, in modern times, there are many innovations in improving fuels, but mainly concerning converting and valuing this form of energy [3,4]. While the use of biomass may have been limited to the direct combustion of branches and trunks in the early days of mankind, today, conversion includes improving fuels through thermochemical conversion technologies, such as torrefaction, pyrolysis and gasification, which are later more efficiently used in combustion recovery processes [5,6].

This recovery process may allow incorporating a set of materials that are not commonly used, mainly due to several unfavorable characteristics, such as high moisture content, excess of inert materials, low-density, and lower calorific value. These properties contributed to the exclusive use of materials presenting characteristics classified as good [7]. This segregation, besides the preference for some species, also includes the preference for specific parts, such as trunks, neglecting less favorable parts, such as branches, leaves, bark, or roots [8]. 
One of the sectors where the use and reincorporation of waste materials into supply chains can be presented as a necessity is the agro-industrial sector, now following sustainability and circular economy [9-11]. Within this so diverse sector, the wine industry emerges as an excellent field for developing this trend. First, due to the diversity of residual forms available, such as bagasse, stalks, or pruning materials, but also due to the quantities cyclically produced, which may cause environmental problems, such as $\mathrm{CO}_{2}$ emissions during uncontrolled waste burning, its disposal in landfills, or simple abandonment in piles [12-14].

The use of vine pruning materials in pyrolysis processes is a possibility that allows the resolution of several environmental problems, namely those related to managing the large volumes generated annually, but also adding some value to the materials, since its elimination results mostly in costs [15-17]. In this way, recovering these materials creates new value chains and introduces a circular economy perspective, contributing to the sector's sustainability [18-20]. Biochar production converts the waste into materials with higher added value, higher energy density, which are not perishable by biological agents, hydrophobic, and even can be used to replace coal, serving as a mitigating agent for climate changes [21,22]. This biochar can also be used in soil amendment functions, taking advantage of its adsorption capacity to capture polluting elements or to fix nutrients, and serves as a sink, sequestrating carbon in the soil, and thereby contribute once again to mitigate climate changes $[13,23]$.

This study aims to characterize vine pruning material, analyze its chemical composition, and understand the behavior of the materials when submitted to a pyrolysis process. Possibilities for use are also discussed, with a perspective of adding value to the materials and introducing circular economy processes in the wine industry by implementing new practices. We discuss how introducing these circular economy practices can lead to the sustainability of the sector, namely through the resolution of environmental problems and creating new value chains for waste materials.

\section{Materials and Methods}

\subsection{Sampling and Material Preparation}

The biomass of vine pruning was collected during December 2020 in vineyards located in the Ponte de Lima region (North Portugal). The material was subsequently cut into portions with dimensions close to $3 \mathrm{~cm}$, as shown in Figure 1, to facilitate drying and grinding.

For biochar production, we used a BARRACHA (model K-3) high-temperature furnace, which uses electrical resistances for generating heat. This furnace also presents a built-in thermal controller that enables programming four temperature stages with respective residence times. The preparation of the samples was made with the aid of conventional aluminum paper used to wrap the material into a cylindrical shape. Because the aluminum paper has two distinct sides, it should be noted that the opaque part of the sheet must be directed towards the outside so that during the carbonization process, the heat is not reflected.

The definition of temperature stages and a scheme of the programmable stages are presented in Table 1. Temperatures were chosen based on the definition presented by Nunes (2020) [24], while the residence times were selected based on the studies by Ribeiro et al. (2018), Sá et al. (2020) and Nunes et al. $(2021)[20,25,26]$. Figure 2 shows the material wrapped in the aluminum foil and the material after the biochar production phase. 


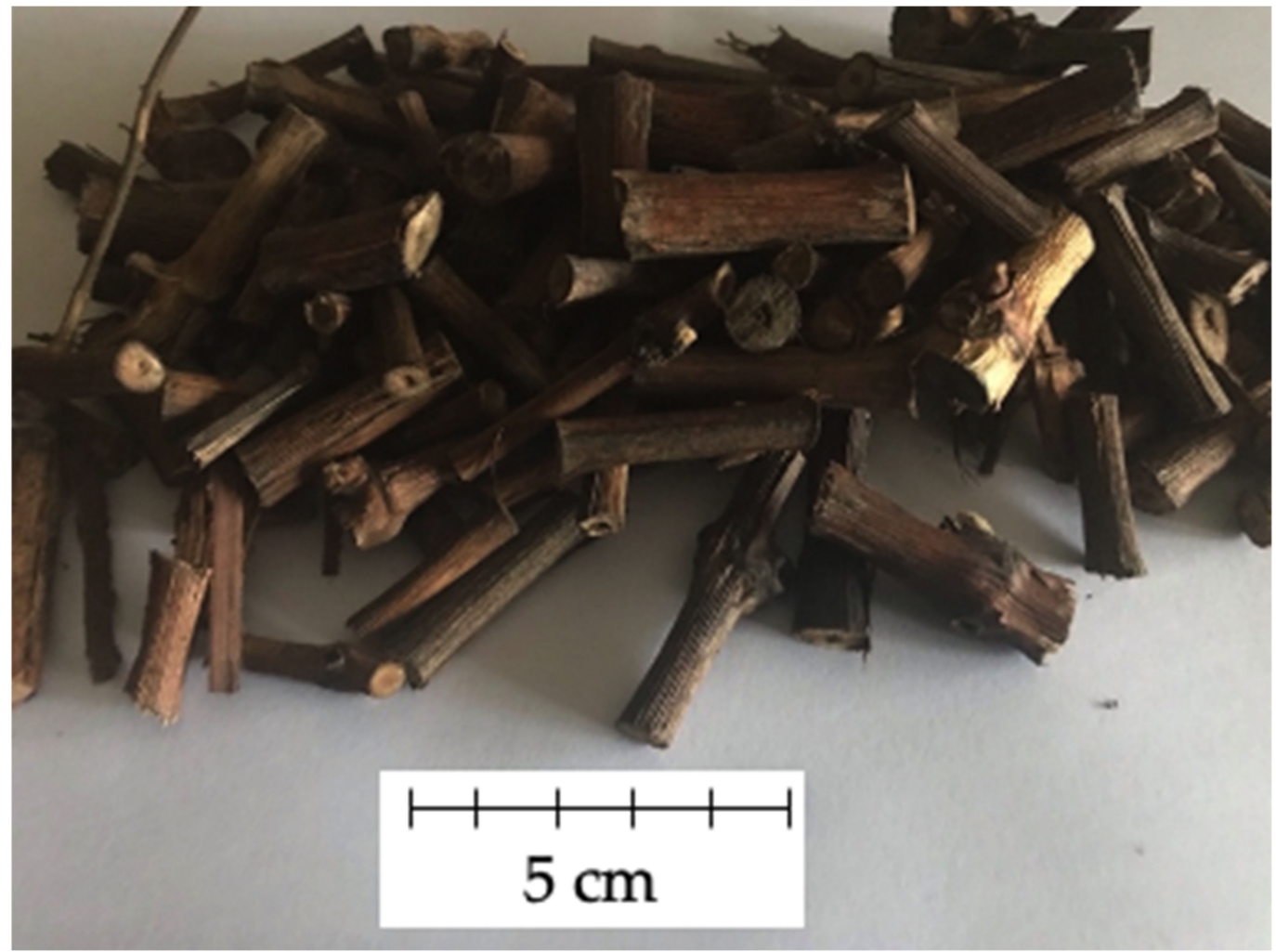

Figure 1. Samples collected for the characterization and biochar production tests.

Table 1. Scheme of the programmable stages according to the temperature and residence time.

\begin{tabular}{ccccc}
\hline Stages & Carbonization Steps & Temperature $\left({ }^{\circ} \mathbf{C}\right)$ & Residence Time (min) & $\begin{array}{c}\text { Heating Rate } \\
\left({ }^{\circ} \mathbf{C} . \mathbf{m i n}-\mathbf{1}\right)\end{array}$ \\
\hline 1 & Initial heating/pre-drying & $\mathrm{T}_{\text {room }}-180$ & 30 & 5 \\
\hline 2 & Post-drying and intermediate heating & $180-3400$ & 60 & 3.7 \\
\hline 3 & Carbonization & 400 & 90 & - \\
\hline 4 & Cooling & $400-50{ }^{\circ} \mathrm{C}$ & Until can safely open the furnace \\
\hline
\end{tabular}

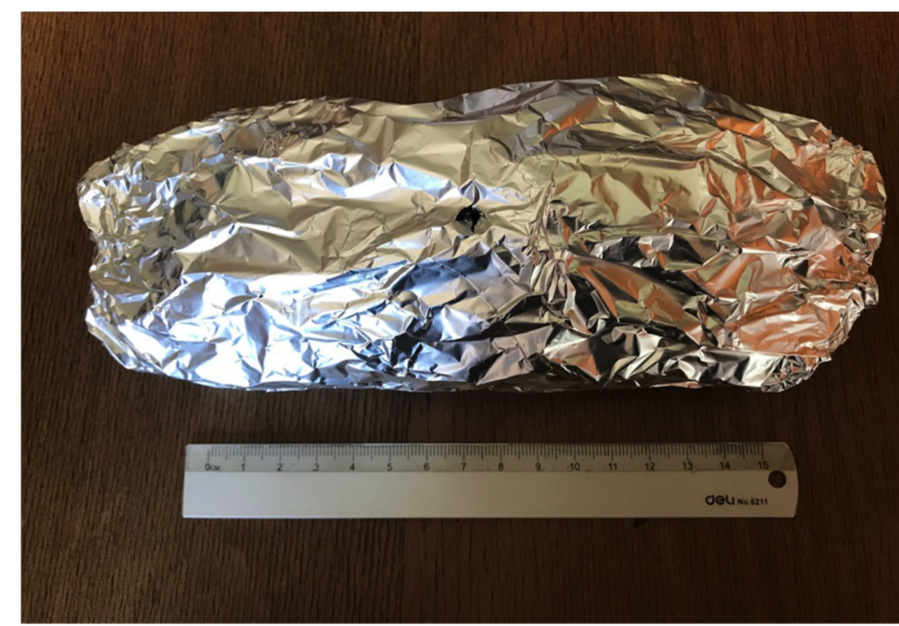

(a)

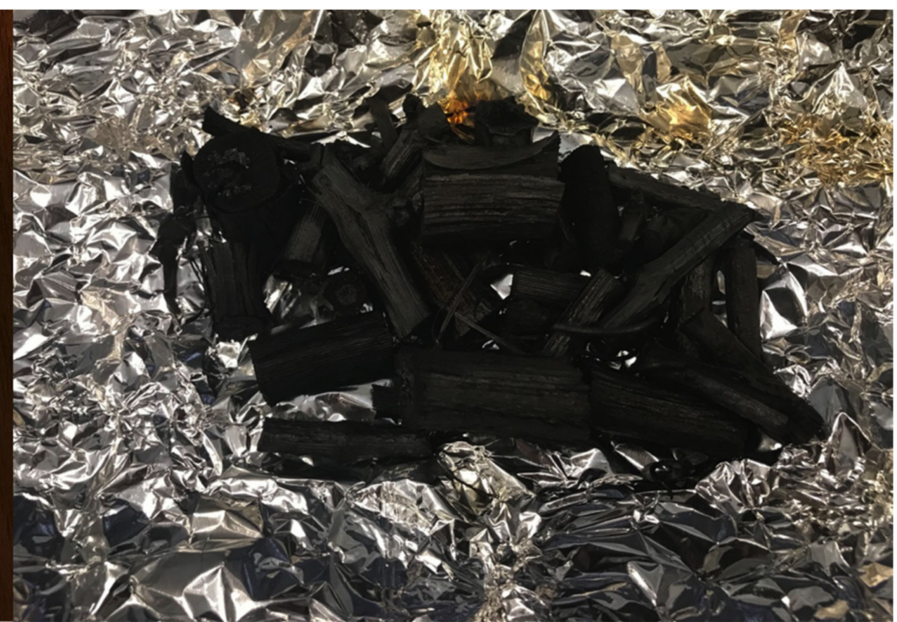

(b)

Figure 2. (a) Material wrapped in the aluminum foil; (b) produced biochar. 


\subsection{Laboratory Characterization Tests}

To carry out the laboratory characterization tests, the procedures described in the following reference standards were used:

- ISO 17225-1: 2014-Solid biofuels—Fuel specifications and classes-Part 1: General requirements.

- ISO 16948: 2015—Solid biofuels—Determination of total content of carbon, hydrogen and nitrogen.

- ISO 16967: 2015-Solid biofuels—Determination of major elements- $\mathrm{Al}, \mathrm{Ca}, \mathrm{Fe}, \mathrm{Mg}, \mathrm{P}$, $\mathrm{K}, \mathrm{Si}, \mathrm{Na}$ and Ti.

- ISO 16968: 2015-Solid biofuels-Determination of minor elements-Ar, Cd, Cobalt, $\mathrm{Cr}$, Copper, $\mathrm{Hg}, \mathrm{Mn}, \mathrm{Mo}, \mathrm{Ni}, \mathrm{Pb}, \mathrm{Sb}, \mathrm{V}$ and $\mathrm{Zn}$.

- ISO 16994: 2016-Solid biofuels-Determination of total content of sulfur and chlorine.

- ISO 18125: 2017-Solid biofuels-Determination of calorific value.

- ISO 21404: 2020(en)—Solid biofuels—Determination of ash melting behavior.

- ASTM E870-82(2019) - Standard Test Methods for Analysis of Wood Fuels (with reference documents: ASTM D1102—84(2021)—Standard Test Method for Ash in Wood; ASTM E871 - 82(2019) — Standard Test Method for Moisture Analysis of Particulate Wood Fuels; ASTM E871-82(2019)—Standard Test Method for Moisture Analysis of Particulate Wood Fuels) —Determination of proximate analysis by thermogravimetry.

\section{Results and Discussion}

The materials resulting from vine pruning are normally used as firewood for heating and as fuel in bakery and restaurant ovens [27]. In Portugal, for example, traditionally, it is the preferred fuel for piglet roasters restaurants in the Bairrada region [28]. However, given the considerable volumes of biomass produced annually throughout the country, it is very difficult to collect and use it, given the dispersion of wine production throughout the territory, which is usually abandoned, or else eliminated by burning the leftovers $[29,30]$. Despite the recognized properties as a fuel, previously reported in several works, such as those by Duca et al. (2016), Torreiro et al. (2020), Nunes et al. (2020) or Atelge et al. (2020), where several characterizations of materials and different forms of energy recovery, such as anaerobic digestion, pyrolysis or gasification, are presented, still exists a deep lack of knowledge concerning creating value chains using these materials and about the best options to manage the amounts yearly generated [31-34].

The results obtained in the thermogravimetric analysis for vine pruning samples, dry and carbonized material, are presented in Table 2.

Table 2. TGA results.

\begin{tabular}{ccccccccc}
\hline & \multicolumn{2}{c}{ Moisture (\%) } & \multicolumn{2}{c}{ Volatiles (\%) } & \multicolumn{2}{c}{ Ashes (\%) } & \multicolumn{2}{c}{ Fixed Carbon (\%) } \\
\cline { 2 - 9 } & Dry & Biochar & Dry & Biochar & Dry & Biochar & Dry & Biochar \\
\hline Sample 1 & 3.74 & 1.35 & 77.83 & 33.33 & 1.42 & 7.30 & 19.51 & 59.36 \\
Sample 2 & 3.77 & 1.37 & 77.84 & 34.51 & 1.41 & 7.33 & 19.46 & 58.16 \\
Sample 3 & 3.51 & 1.30 & 77.72 & 33.85 & 1.42 & 7.22 & 19.78 & 58.94 \\
Average & 3.67 & 1.34 & 77.80 & 33.90 & 1.42 & 7.28 & 19.58 & 58.82 \\
Standard deviation & 0.14 & 0.03 & 0.07 & 0.59 & 0.01 & 0.06 & 0.17 & 0.61 \\
Confidence & 0.16 & 0.04 & 0.08 & 0.67 & 0.01 & 0.07 & 0.20 & 0.69 \\
\hline
\end{tabular}

After drying in a laboratory oven for $12 \mathrm{~h}$ at $90{ }^{\circ} \mathrm{C}$, the sample material showed an average value of $3.67 \pm 0.16 \%$. The volatile content showed an average value of $77.80 \pm 0.08 \%$. The ash content showed an average value of $1.42 \pm 0.01 \%$. The fixed carbon content showed an average value of $19.58 \pm 0.20 \%$. The moisture content after carbonization of the samples showed an average value of $1.34 \pm 0.04 \%$. The volatile content showed an average value of $33.90 \pm 0.67 \%$. The ash content showed an average value of $7.28 \pm 0.07 \%$. The fixed carbon content showed an average value of $58.82 \pm 0.69 \%$. 
The thermogravimetric analysis (Figure 3) demonstrated that the moisture content changes to residual values, reaching a minimum value of $1.34 \%$, in line with the results obtained by Ren et al. (2013), with values below $2.00 \%$ for temperatures of $300{ }^{\circ} \mathrm{C}$, or in work by Barzegar et al. (2020), which obtained 1.90\% moistures for the same conditions [35,36]. As expected, the volatile content had a significant reduction, going from the initial $77.80 \%$ to a value of $33.90 \%$. This result is justified by the loss of mass verified since this occurs mainly due to the volatilization of hemicellulose, which is the compound responsible for forming most of the volatile organic compounds and structural water [37-40]. As the ash consists essentially of nonvolatilizable metal oxides, the increase observed in its content is justified with the verified mass loss since it is proportional [41,42]. With the release of oxygenated compounds, the fixed carbon content increased from $19.58 \%$ to $58.82 \%$. This increase in the fixed carbon content is one of the advantages of the thermochemical conversion process since it allows the obtention of a material with higher carbon content and greater viability for energy recovery, but also because of the possibility that it opens for other uses, namely in soil amendment, due to the adsorbent capacity that biochar presents, and which has been widely studied [43-45].

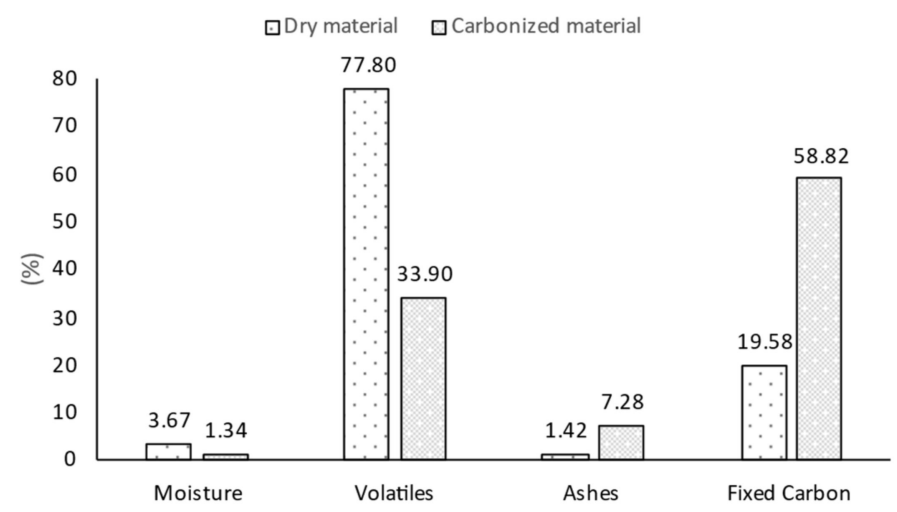

Figure 3. Evolution of moisture, volatiles, ashes and fixed carbon contents after carbonization of vine pruning.

The results obtained for CHNO analysis are presented in Table 3.

Table 3. CHNO results.

\begin{tabular}{ccccccccc}
\hline & \multicolumn{2}{c}{ C (\%) } & \multicolumn{2}{c}{ H (\%) } & \multicolumn{2}{c}{ N (\%) } & \multicolumn{2}{c}{ O (\%) } \\
\hline & Dry & Biochar & Dry & Biochar & Dry & Biochar & Dry & Biochar \\
\hline Sample 1 & 47.12 & 73.55 & 6.36 & 4.69 & 0.71 & 1.209 & 45.79 & 20.53 \\
Sample 2 & 46.48 & 73.62 & 6.42 & 4.60 & 0.62 & 1.213 & 46.47 & 20.55 \\
Sample 3 & 45.23 & 73.40 & 6.05 & 4.62 & 0.28 & 1.175 & 48.42 & 20.78 \\
Average & 46.28 & 73.53 & 6.28 & 4.64 & 0.54 & 1.20 & 46.89 & 20.62 \\
Standard deviation & 0.96 & 0.11 & 0.20 & 0.05 & 0.23 & 0.02 & 1.37 & 0.14 \\
Confidence & 1.09 & 0.13 & 0.22 & 0.05 & 0.26 & 0.02 & 1.55 & 0.16 \\
\hline
\end{tabular}

The $C$ content for the dry samples showed an average value of $46.28 \pm 1.09$. The $\mathrm{H}$ content showed an average value of $6.28 \pm 0.22$. The $\mathrm{N}$ content showed an average value of $0.54 \pm 0.26 \%$. The $\mathrm{O}$ content showed an average value of $46.89 \pm 1.55$. The $\mathrm{C}$ content for the biochar samples showed an average value of $73.53 \pm 0.13 \%$. The $\mathrm{H}$ content showed an average value of $4.64 \pm 0.05 \%$. The $\mathrm{N}$ content showed an average value of $1.200 \pm 0.02 \%$. The $\mathrm{O}$ content showed an average value of $20.62 \pm 0.16$.

The trend of evolution of the $\mathrm{CHNO}$ contents after the carbonization of the material (Figure 4) demonstrated consistency with previous studies, and the consonance with the behavior revealed by other forms of biomass, with the values of the $\mathrm{C}$ content showing a significant increase, from $46.28 \%$ to $73.53 \%$, while, in the opposite direction, the O content 
drops from the initial $46.89 \%$ to $20.62 \%$, after the carbonization process. These results are in line with the recognized elimination of oxygenated products resulting from the degradation of hemicellulose [13,46-48]. The N content showed a slight increase, from $0.54 \%$ to $1.20 \%$, associated with its concentration, justified by the average weight loss of $78.31 \pm 1.00 \%$ observed, while the $\mathrm{H}$ content showed a slight decrease, from the initial $6.28 \%$ to $4.64 \%$, associated with its contribution to forming volatile organic compounds [49]. In addition, the analysis of the $\mathrm{H} / \mathrm{C}$ and $\mathrm{O} / \mathrm{C}$ ratios, which show a sharp decrease, indicates increased calorific value, since after being projected in a van Krevelen diagram, biochar will present a position closer to the origin of the graphic when compared to the projection of the ratios obtained with the $\mathrm{CHO}$ contents for the dry samples of vine pruning.

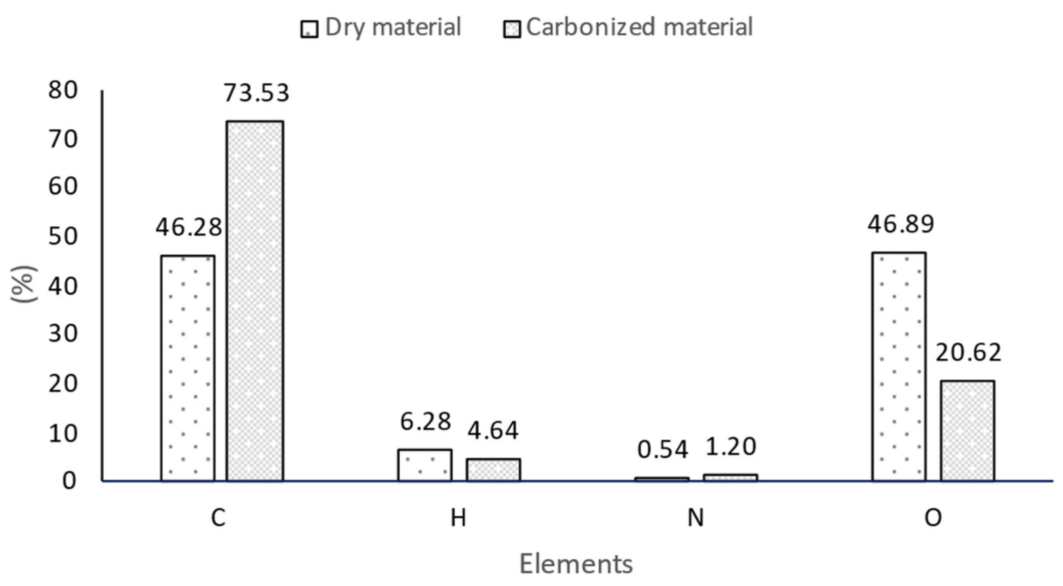

Figure 4. Evolution of $\mathrm{CHNO}$ contents after carbonization of vine pruning.

The oxygen content of a fuel is a determining factor for the efficiency of its conversion during combustion. The availability of oxygen in the fuel increases the combination with hydrogen to produce water, which subsequently lowers the temperature of the flame. As shown in Figure 5, pyrolysis causes a reduction in the oxygen content and increases the carbon content without, however, significantly altering the hydrogen content. As saw earlier, the pyrolysis process, like what happens with the biomass torrefaction process, leads to the volatilization of one of the constituent compounds of biomass, which is hemicellulose, mainly in the temperature range between $220^{\circ} \mathrm{C}$ and $320^{\circ} \mathrm{C}$, as described by Nunes et al. (2020) [24]. When this temperature is exceeded, accelerated cellulose decomposition begins. However, the procedure is similar and continues to lean towards the elimination of oxygen [50,51].

This reduction in the oxygen content significantly improves the combustibility of the biochar, but this may not even be the greatest advantage and the best way to enhance this material since, as recent studies indicate, its use as a soil amendment to take advantage of its adsorbent properties for the removal of polluting elements, or even the fixation of nutrients, can be an advantage with a more positive impact than energy recovery $[52,53]$. Another possibility that emerges from incorporating biochar in soils is related to the carbon sequestration capacity, contributing to the mitigation of climate changes since it is a negative emission technology $[54,55]$. 


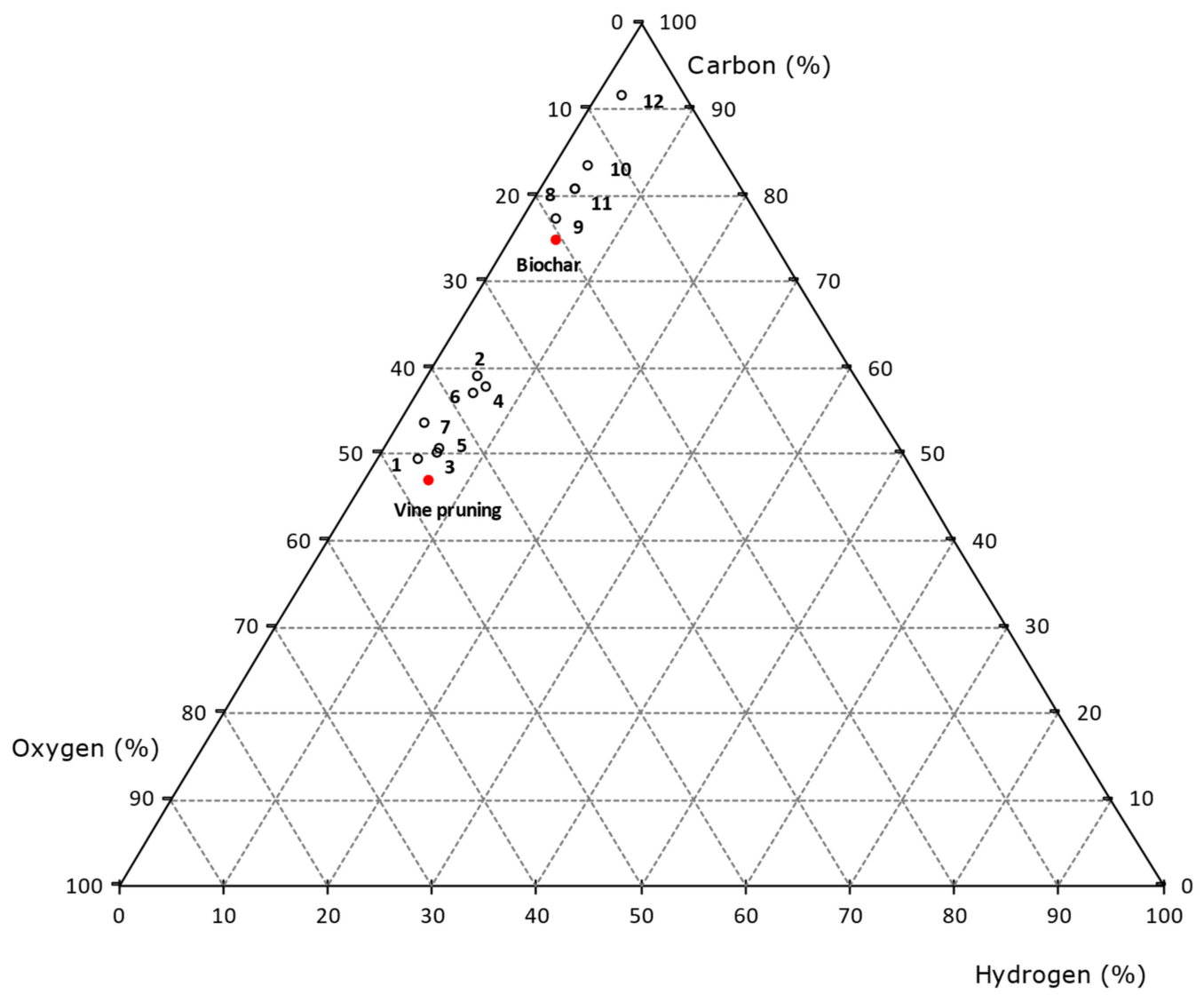

Figure 5. Triangular diagram representing $\mathrm{CHO}$ contents. As can be seen, the content of $\mathrm{CHO}$ for vine pruning is similar to those found by Nunes et al. (2020) and Sá et al. (2020), both for dry and carbonized samples [26,33]. Vine pruning and biochar are the samples analyzed in the present work; samples 1 to 6 and samples 7 to 12 are, respectively, dry samples and carbonized samples from previous referred studies, as follows: 1 and 7-rice husks; 2 and 8-almond shells; 3 and 9-kiwi pruning; 4 and 10-olive pomace; 5 and 11-Pinus pinaster; and 6 and 12-Eucalyptus globulus.

The results obtained in the determination of $\mathrm{S}$ and $\mathrm{Cl}$ are shown in Table 4.

Table 4. $\mathrm{S}$ and $\mathrm{Cl}$ results.

\begin{tabular}{ccccc}
\hline & \multicolumn{2}{c}{ S (ppm) } & \multicolumn{2}{c}{ Cl (ppm) } \\
\hline & Dry & Biochar & Dry & Biochar \\
\hline Sample 1 & 181 & 186 & 92.7 & 1.3 \\
Sample 2 & 184 & 179 & 13.8 & 6.5 \\
Sample 3 & 190 & 183 & 16.4 & 7.7 \\
Average & 185 & 183 & 41.0 & 5.2 \\
Standard deviation & 5 & 3.5 & 44.8 & 3.4 \\
Confidence & 5 & 4 & 50.7 & 3.9 \\
\hline
\end{tabular}

For dried samples, the $S$ content showed an average value of $185 \pm 5 \mathrm{ppm}$. The $\mathrm{Cl}$ content showed an average value of $41.0 \pm 50.7 \mathrm{ppm}$. For carbonized samples, the $S$ content showed an average value of $183 \pm 4 \mathrm{ppm}$. The $\mathrm{Cl}$ content showed an average value of $5.2 \pm 3.9$ ppm.

It is very common for different forms of biomass to have low sulfur contents, as is evidenced in several studies, such as those by Arias et al. (2008) and Simonic et al. (2020) $[56,57]$. The result obtained proves this trend since the value obtained is low, being in line with the values allowed, for example, by the ENplus ${ }^{\circledR}$ standard, which is $0.04 \%$ [58]. Chlorine, on the other hand, can appear in abundant quantities, being one of the agents responsible for the corrosion of combustion equipment that most contributes to damage 
and maintenance stops $[59,60]$. However, a recent study by Sá et al. (2020) proved that chlorine could be eliminated from the final product through thermochemical conversion processes, as seen in the results obtained, in which from the initial $0.0041 \%$, it changed to $0.0005 \%$, that is, to a practically null value, as is presented in Figure 6 [26].

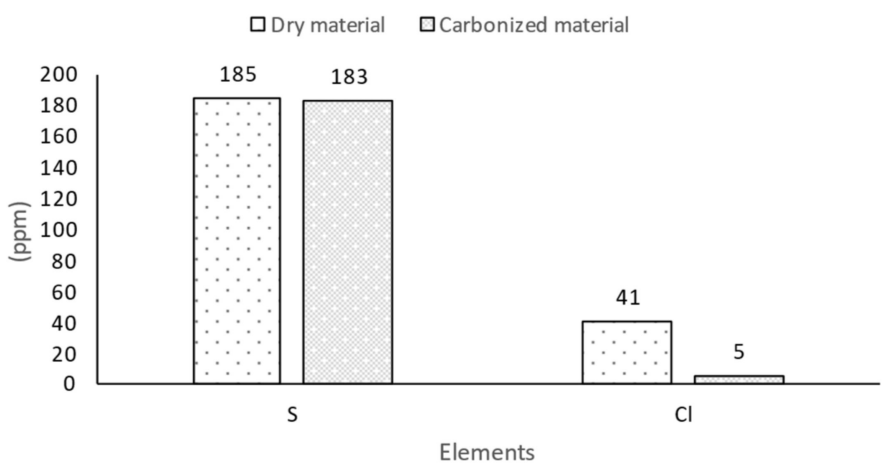

Figure 6. Evolution of $\mathrm{S}$ and $\mathrm{Cl}$ contents after carbonization of vine pruning.

The results obtained for HHV and LHV are shown in Table 5.

Table 5. HHV and LHV results.

\begin{tabular}{ccccc}
\hline & \multicolumn{2}{c}{ HHV (MJ/kg) } & \multicolumn{2}{c}{ LHV (MJ/kg) } \\
\hline & Dry & Biochar & Dry & Biochar \\
\hline Sample 1 & 18.95 & 29.84 & 17.58 & 28.84 \\
Sample 2 & 18.95 & 29.71 & 17.58 & 28.72 \\
Sample 3 & 18.95 & 29.78 & 17.58 & 28.78 \\
Average & 18.95 & 29.78 & 17.58 & 28.78 \\
Standard deviation & 0.002 & 0.006 & 0.002 & 0.006 \\
Confidence & 0.002 & 0.007 & 0.002 & 0.007 \\
\hline
\end{tabular}

The HHV of the dry samples showed an average value of $18.95 \pm 0.002 \mathrm{MJ} / \mathrm{kg}$. LHV showed an average value of $17.58 \pm 0.002 \mathrm{MJ} / \mathrm{kg}$. The HHV of carbonized samples presented an average value of $29.78 \pm 0.007 \mathrm{MJ} / \mathrm{kg}$. The LHV presented an average value of $28.78 \pm 0.007 \mathrm{MJ} / \mathrm{kg}$.

In previous works, such as those carried out by San José et al. (2013), where developing a novel conical combustor for thermal exploitation of vineyard pruning wastes is presented, the results obtained to follow the values obtained in the present work [61]. Also, in the work of Bilandzija (2012), who assesses the energy potential of several fruits pruned biomass in Croatia, including vine pruning, the average values of HHV and LHV for dry materials are confirmed [62]. The use of biowastes is a topic with growing and current interest, namely due to introducing the concepts of circular economy and sustainability in the wine industry and the agrarian environment in general. Several recent studies address the theme and present results on characterizing materials, even comparing variations between the different vine varieties used, as is the case of the works by Sun et al. (2020), Acquadro et al. (2020), Bisaglia \& Romano (2018) or Loupit et al. (2020) [63-65], but also in the perspective of new valuation methodologies, as is the case presented by Allesina et al. (2018), which addresses using vine pruning as fuel in small-scale gasifiers [66], or the case presented by Margaritis et al. (2020), which deals with the impact of torrefaction on the characteristics of vine pruning fuel [67]. Regarding the pyrolysis or carbonization process, there are also several works already in existence, such as those by Tag et al. (2016), Azuara et al. (2017), Dunnigan et al. (2018), Hoffmann et al. (2019) and Sun et al. (2020), and that validate the results obtained here $[23,63,68-70]$. As can be seen in Figure 7 , the heating value for carbonized materials increases by more than $50 \%$. This demonstrates the advantages of using a thermochemical conversion process such as pyrolysis to valorize 
these residual materials, both for the potential energy generated and associated logistical advantages. Such logisticl advantages include reduction of volume, energy densification and ease of storage, since the materials, being hydrophobic, can be stored outside, and because they do not rot or are subject to biological activity, as demonstrated in the work of Nunes et al. (2021) [20].

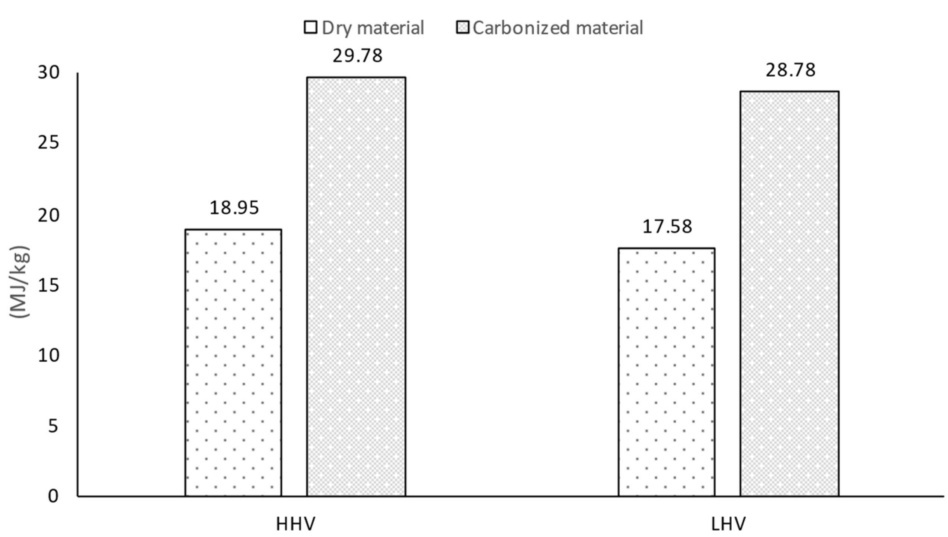

Figure 7. Evolution of HHV and LHV after carbonization of vine pruning.

The results obtained concerning the mass loss for the carbonized samples of vine pruning are shown in Table 6.

Table 6. Determination of mass loss of carbonized samples of vine pruning.

\begin{tabular}{cccc}
\hline & Initial Mass (g) & Final Mass (g) & Mass Loss (\%) \\
\hline Sample 1 & 229.18 & 47.11 & 79.44 \\
Sample 2 & 261.70 & 60.01 & 77.07 \\
Sample 3 & 257.04 & 55.49 & 78.41 \\
Average & 249.31 & 54.20 & 78.31 \\
Standard deviation & 17.59 & 6.55 & 1.00 \\
Confidence & 19.90 & 7.41 & 1.00 \\
\hline
\end{tabular}

The mass loss presented an average value of $78.31 \pm 1.00 \%$. The values verified in the mass loss are in agreement with the values presented in previous works, such as those by Tag et al. (2016) or Nunes et al. (2020) [23,33]. The values presented in the referred works are included in the range $75-80 \%$ for process temperatures of $400{ }^{\circ} \mathrm{C}$ and equivalent residence time.

The results for major elements are shown in Table 7.

Table 7. Major elements results for dry samples.

\begin{tabular}{|c|c|c|c|c|c|c|c|c|c|}
\hline & $\begin{array}{c}\mathrm{Al} \\
(\mathrm{ppm})\end{array}$ & $\underset{(\mathrm{ppm})}{\mathrm{Ca}}$ & $\begin{array}{c}\text { Fe } \\
(\mathrm{ppm})\end{array}$ & $\begin{array}{c}\mathrm{Mg} \\
(\mathrm{ppm})\end{array}$ & $\begin{array}{c}\mathbf{P} \\
(\text { ppm) }\end{array}$ & $\underset{(\mathrm{ppm})}{\mathrm{K}}$ & $\begin{array}{c}\mathrm{Si} \\
(\mathrm{ppm})\end{array}$ & $\begin{array}{c}\mathrm{Na} \\
(\mathrm{ppm})\end{array}$ & $\begin{array}{c}\mathrm{Ti} \\
\text { (ppm) }\end{array}$ \\
\hline Sample 1 & 74.54 & 6972.46 & 31.15 & 1303.74 & 1101.95 & 8120.49 & 188.82 & 407.25 & 2.71 \\
\hline Sample 2 & 53.66 & 7722.37 & 38.57 & 1386.39 & 1077.50 & 8444.39 & 137.45 & 413.72 & 3.48 \\
\hline Sample 3 & 53.44 & 7641.21 & 32.29 & 1387.78 & 1107.98 & 8168.23 & 131.67 & 444.39 & 2.83 \\
\hline Average & 60.55 & 7445.35 & 34.00 & 1359.30 & 1095.81 & 8244.37 & 152.65 & 421.79 & 3.01 \\
\hline Standard deviation & 12.12 & 411.54 & 4.00 & 48.12 & 16.14 & 174.86 & 31.46 & 19.84 & 0.41 \\
\hline Confidence & 13.71 & 465.69 & 4.52 & 54.46 & 18.26 & 197.87 & 35.60 & 22.45 & 0.47 \\
\hline
\end{tabular}

The Al content showed an average value of $60.55 \pm 12.12 \mathrm{ppm}$. The Ca content showed an average value of $7445.35 \pm 465.69 \mathrm{ppm}$. The Fe content showed an average value of $34.00 \pm 4.52 \mathrm{ppm}$. The $\mathrm{Mg}$ content showed an average value of $1359.30 \pm 54.46 \mathrm{ppm}$. The $p$ content showed an average value of $1095.81 \pm 18.26 \mathrm{ppm}$. The K content showed 
an average value of $8244.37 \pm 197.87 \mathrm{ppm}$. The Si content showed an average value of $152.65 \pm 35.60 \mathrm{ppm}$. The Na content showed an average value of $421.79 \pm 22.45 \mathrm{ppm}$. The Ti content showed an average value of $3.01 \pm 0.47 \mathrm{ppm}$.

The results obtained in determining the content of major elements for the carbonized samples of vine pruning are shown in Table 8.

Table 8. Determination of the content of major elements of carbonized samples.

\begin{tabular}{|c|c|c|c|c|c|c|c|c|c|}
\hline & $\begin{array}{c}\mathrm{Al} \\
(\mathrm{ppm})\end{array}$ & $\begin{array}{c}\mathrm{Ca} \\
(\mathrm{ppm})\end{array}$ & $\begin{array}{c}\mathrm{Fe} \\
(\mathrm{ppm})\end{array}$ & $\begin{array}{c}\mathrm{Mg} \\
(\mathrm{ppm})\end{array}$ & $\begin{array}{c}\mathbf{P} \\
(\mathrm{ppm})\end{array}$ & $\begin{array}{c}\mathrm{K} \\
(\mathrm{ppm})\end{array}$ & $\begin{array}{c}\mathrm{Si} \\
(\mathrm{ppm})\end{array}$ & $\begin{array}{c}\mathrm{Na} \\
(\mathrm{ppm})\end{array}$ & $\begin{array}{c}\mathrm{Ti} \\
(\mathrm{ppm})\end{array}$ \\
\hline Sample 1 & 91.80 & $14,219.58$ & 60.64 & 2331.45 & 2317.61 & $16,937.31$ & 182.17 & 422.19 & 5.15 \\
\hline Sample 2 & 73.40 & $14,415.48$ & 50.93 & 2329.09 & 2268.36 & $16,988.84$ & 183.20 & 412.39 & 4.52 \\
\hline Sample 3 & 78.07 & $13,829.52$ & 52.11 & 2314.15 & 2289.80 & $16,392.79$ & 171.07 & 429.53 & 3.68 \\
\hline Average & 81.09 & $14,154.86$ & 54.56 & 2324.90 & 2291.92 & $16,772.98$ & 178.81 & 421.37 & 4.45 \\
\hline Standard deviation & 9.56 & 298.29 & 5.30 & 9.38 & 24.69 & 330.26 & 6.73 & 8.60 & 0.74 \\
\hline Confidence & 10.82 & 337.54 & 6.00 & 10.62 & 27.94 & 373.72 & 7.61 & 9.73 & 0.83 \\
\hline
\end{tabular}

The $\mathrm{Al}$ content showed an average value of $81.09 \pm 10.82 \mathrm{ppm}$. The Ca content showed an average value of $14,154.86 \pm 337.54 \mathrm{ppm}$. The Fe content showed an average value of $54.56 \pm 6.00 \mathrm{ppm}$. The $\mathrm{Mg}$ content showed an average value of $2324.90 \pm 10.62 \mathrm{ppm}$. The $\mathrm{P}$ content showed an average value of $2291.92 \pm 27.94 \mathrm{ppm}$. The K content showed an average value of $16,772.98 \pm 373.72 \mathrm{ppm}$. The $\mathrm{Si}$ content showed an average value of $178.81 \pm 7.61 \mathrm{ppm}$. The Na content showed an average value of $421.37 \pm 9.73 \mathrm{ppm}$. The Ti content showed an average value of $4.45 \pm 0.83 \mathrm{ppm}$.

The results for minor elements are shown in Table 9.

Table 9. Minor elements results for dry samples.

\begin{tabular}{cccccccccc}
\hline & $\begin{array}{c}\mathbf{A s} \\
(\mathbf{p p m})\end{array}$ & $\begin{array}{c}\mathbf{C d} \\
(\mathbf{p p m})\end{array}$ & $\begin{array}{c}\mathbf{C o} \\
(\mathbf{p p m})\end{array}$ & $\begin{array}{c}\mathbf{C r} \\
(\mathbf{p p m})\end{array}$ & $\begin{array}{c}\mathbf{C u} \\
(\mathbf{p p m})\end{array}$ & $\begin{array}{c}\mathbf{M n} \\
(\mathbf{p p m})\end{array}$ & $\begin{array}{c}\mathbf{N i} \\
(\mathbf{p p m})\end{array}$ & $\begin{array}{c}\mathbf{P b} \\
(\mathbf{p p m})\end{array}$ & $\begin{array}{c}\mathbf{Z n} \\
(\mathbf{p p m})\end{array}$ \\
\hline Sample 1 & 0.58 & 0.58 & 0.40 & 0.48 & 23.16 & 39.64 & 0.63 & 0.29 & 14.51 \\
Sample 2 & 0.88 & 0.34 & 0.20 & 0.34 & 26.48 & 43.44 & 0.41 & 0.10 & 14.53 \\
Sample 3 & 0.73 & 0.39 & 0.32 & 0.04 & 25.15 & 40.95 & 0.13 & 0.09 & 78.40 \\
Average & 0.73 & 0.44 & 0.31 & 0.29 & 24.93 & 41.34 & 0.39 & 0.16 & 35.81 \\
Standard deviation & 0.15 & 0.13 & 0.10 & 0.22 & 1.67 & 1.93 & 0.25 & 0.11 & 36.88 \\
Confidence & 0.17 & 0.14 & 0.11 & 0.25 & 1.89 & 2.18 & 0.28 & 0.13 & 41.73 \\
\hline
\end{tabular}

The As content showed an average value of $0.73 \pm 0.17 \mathrm{ppm}$. The $\mathrm{Cd}$ content showed an average value of $0.44 \pm 0.14 \mathrm{ppm}$. The Co content showed an average value of $0.31 \pm 0.11 \mathrm{ppm}$. The $\mathrm{Cr}$ content showed an average value of $0.29 \pm 0.25 \mathrm{ppm}$. The $\mathrm{Cu}$ content showed an average value of $24.93 \pm 1.89 \mathrm{ppm}$. The Mn content showed an average value of $41.34 \pm 2.18 \mathrm{ppm}$. The Ni content showed an average value of $0.39 \pm 0.28 \mathrm{ppm}$. $\mathrm{The} \mathrm{Pb}$ content showed an average value of $0.16 \pm 0.13 \mathrm{ppm}$. The $\mathrm{Zn}$ content showed an average value of $35.81 \pm 41.73 \mathrm{ppm}$.

The results obtained in determining the content of minor elements for the carbonized samples are shown in Table 10.

Table 10. Determination of the content of minor elements in carbonized samples of vine pruning.

\begin{tabular}{cccccccccc}
\hline & $\begin{array}{c}\text { As } \\
(\mathbf{p p m})\end{array}$ & $\begin{array}{c}\mathbf{C d} \\
(\mathbf{p p m})\end{array}$ & $\begin{array}{c}\mathbf{C o} \\
(\mathbf{p p m})\end{array}$ & $\begin{array}{c}\mathbf{C r} \\
(\mathbf{p p m})\end{array}$ & $\begin{array}{c}\mathbf{C u} \\
(\mathbf{p p m})\end{array}$ & $\begin{array}{c}\mathbf{M n} \\
(\mathbf{p p m})\end{array}$ & $\begin{array}{c}\mathbf{N i} \\
(\mathbf{p p m})\end{array}$ & $\begin{array}{c}\mathbf{P b} \\
(\mathbf{p p m})\end{array}$ & $\begin{array}{c}\mathbf{Z n} \\
(\mathbf{p p m})\end{array}$ \\
\hline Sample 1 & 2.96 & 0.07 & 0.11 & 0.11 & 45.47 & 87.53 & 0.22 & 0.83 & 55.52 \\
Sample 2 & 2.73 & 0.00 & 0.00 & 0.00 & 46.63 & 87.58 & 0.03 & 0.77 & 51.59 \\
Sample 3 & 2.69 & 0.00 & 0.00 & 0.00 & 45.44 & 85.70 & 0.00 & 0.59 & 51.55 \\
Average & 2.79 & 0.02 & 0.04 & 0,04 & 45.85 & 86.94 & 0.08 & 0.73 & 52.89 \\
Standard deviation & 0.146 & 0.040 & 0.064 & 0.064 & 0.679 & 1.071 & 0.119 & 0.125 & 2.281 \\
Confidence & 0.165 & 0.046 & 0.072 & 0.072 & 0.768 & 1.212 & 0.135 & 0.141 & 2.581 \\
\hline
\end{tabular}


The As content showed an average value of $2.79 \pm 0.165 \mathrm{ppm}$. The Cd content showed an average value of $0.02 \pm 0.046 \mathrm{ppm}$. The Co content showed an average value of $0.04 \pm 0.072 \mathrm{ppm}$. The $\mathrm{Cr}$ content showed an average value of $0.04 \pm 0.072 \mathrm{ppm}$. The $\mathrm{Cu}$ content showed an average value of $45.85 \pm 0.768 \mathrm{ppm}$. The Mn content showed an average value of $86.94 \pm 1.212 \mathrm{ppm}$. The Ni content showed an average value of $0.08 \pm 0.135 \mathrm{ppm}$. The $\mathrm{Pb}$ content showed an average value of $0.73 \pm 0.141 \mathrm{ppm}$. The $\mathrm{Zn}$ content showed an average value of $52.89 \pm 2.581 \mathrm{ppm}$.

Figures 8 and 9 show, respectively, the evolution of major and minor elements present in the analyzed vine pruning biomass. As can be seen, and in line with the average loss of mass observed in the tests, there is a tendency for metallic elements to concentrate since they are not eliminated during the volatilization process that occurs during pyrolysis. The same trend was confirmed by the work of Kraiem et al. (2016) or Picchi et al. (2013) [71,72]. This issue is extremely important, mainly because these elements, which will be found essentially in the form of metal oxides, are the main ones responsible for the phenomena of fouling and slagging that occur in energy recovery systems. Hence, its characterization is particularly important [73].

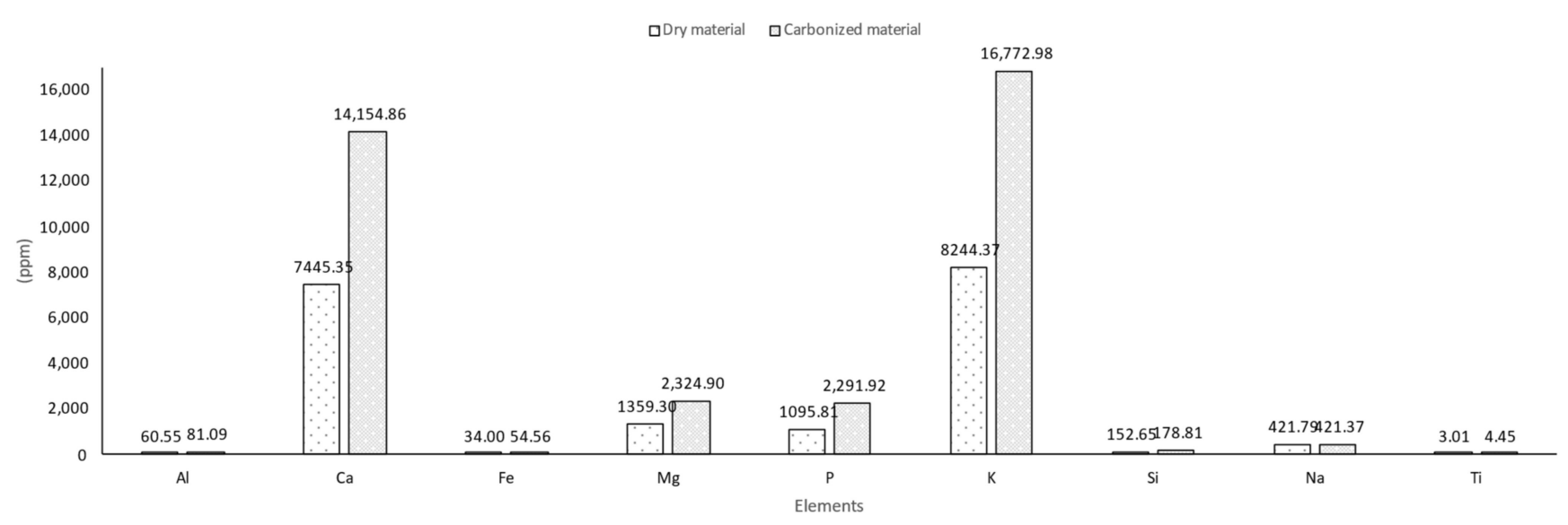

Figure 8. Evolution of the contents of major elements after the carbonization of vine pruning.

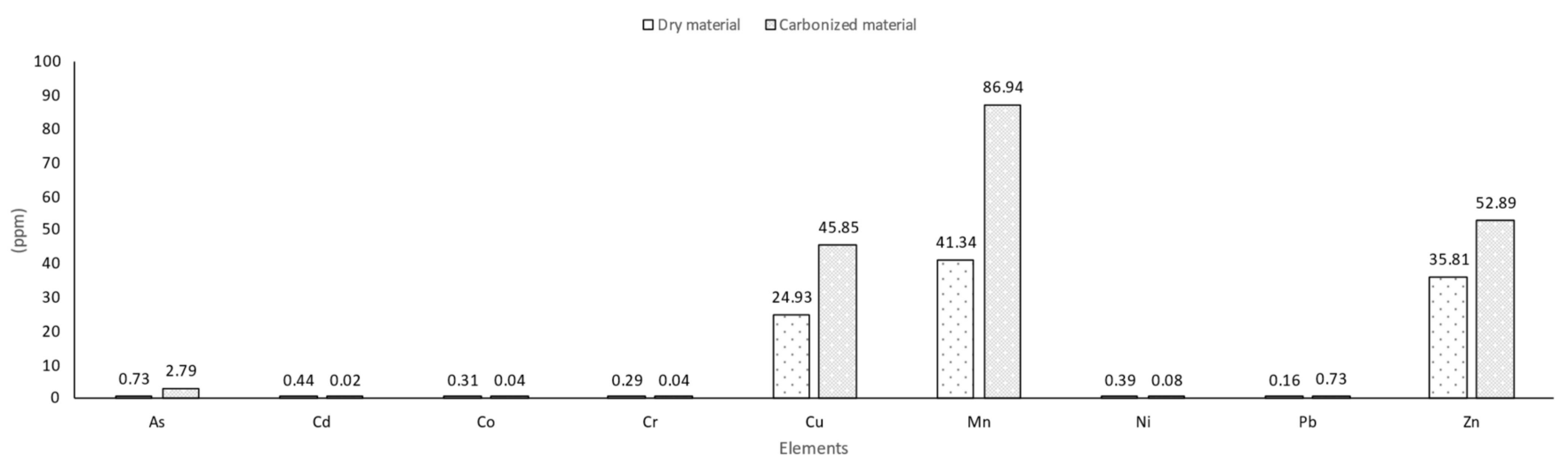

Figure 9. Evolution of minor elements content after carbonization of vine pruning.

\section{Conclusions}

The wine sector is responsible for generating high volumes of waste, which until the present date, has not been treated in a way to be recovered. The uses of this type of waste are rare, in addition to the traditional ones, essentially as firewood, with the elimination of the remaining volumes carried out using, normally, the uncontrolled burning of these materials, without using the generated energy. In this way, using a process such as pyrolysis to recover residues from vine pruning creates a product with higher added value, allowing its use as fuel, but also in soil amendment, and even for carbon sequestration, contributing 
to the mitigation of climate changes. The results obtained confirm the quality of the fuel produced, revealing a significant increase in the heating value and the carbon content. This perspective on the use and recovery of waste resulting from the wine industry fits in with the assumption of policies to introduce processes based on the circular and regenerative economy to implement sustainability principles in the sector.

Author Contributions: Conceptualization, A.I.F., A.C.R., A.M.R. and L.J.R.N.; methodology, A.I.F., A.C.R., J.C.O.M. and L.J.R.N.; validation, A.I.F., A.C.R., A.M.R., J.C.O.M. and L.J.R.N.; formal analysis, A.I.F., A.C.R., A.M.R. and L.J.R.N.; investigation, A.I.F., A.C.R., A.M.R. and L.J.R.N.; resources, A.C.R. and L.J.R.N.; data curation, A.I.F., A.C.R., A.M.R. and J.C.O.M.; writing—original draft preparation, A.I.F., A.C.R. and L.J.R.N.; writing-review and editing, A.C.R., A.M.R., J.C.O.M. and L.J.R.N.; visualization, A.I.F. and L.J.R.N.; supervision, L.J.R.N. and J.C.O.M.; project administration, L.J.R.N. and J.C.O.M. All authors have read and agreed to the published version of the manuscript.

Funding: This research results from the project TECH—Technology, Environment, Creativity and Health, Norte-01-0145-FEDER-000043, supported by Norte Portugal Regional Operational Program (NORTE 2020), under the PORTUGAL 2020 Partnership Agreement, through the European Regional Development Fund (ERDF). L.J.R.N. was supported by proMetheus, Research Unit on Energy, Materials and Environment for Sustainability_UIDP/05975/2020, funded by national funds through FCT—Fundação para a Ciência e Tecnologia.

Institutional Review Board Statement: Not applicable.

Informed Consent Statement: Not applicable.

Data Availability Statement: The data presented in this study are available per request to the corresponding author.

Acknowledgments: The authors would like to acknowledge the companies YGE-Yser Green Energy SA and AFS-Advanced Fuel Solutions SA, both in Portugal, for the execution of the laboratory tests.

Conflicts of Interest: The authors declare no conflict of interest.

\section{References}

1. Kennedy, G.E. From the ape's dilemma to the weanling's dilemma: Early weaning and its evolutionary context. J. Hum. Evol. 2005, 48, 123-145. [CrossRef] [PubMed]

2. Nunes, L.; Matias, J.C.; Catalao, J.P. Wood pellets as a sustainable energy alternative in Portugal. Renew. Energy 2016, 85, 1011-1016. [CrossRef]

3. Isaksson, R.; Johansson, P.; Fischer, K. Detecting supply chain innovation potential for sustainable development. J. Bus. Ethics 2010, 97, 425-442. [CrossRef]

4. Nunes, L.J.; Matias, J.C. Biomass torrefaction as a key driver for the sustainable development and decarbonization of energy production. Sustainability 2020, 12, 922. [CrossRef]

5. Guo, M.; Song, W.; Buhain, J. Bioenergy and biofuels: History, status, and perspective. Renew. Sustain. Energy Rev. 2015, 42, 712-725. [CrossRef]

6. Rodrigues, A.; Loureiro, L.; Nunes, L. Torrefaction of woody biomasses from poplar SRC and Portuguese roundwood: Properties of torrefied products. Biomass Bioenergy 2018, 108, 55-65. [CrossRef]

7. Nunes, L.J. Torrefied Biomass as an Alternative in Coal-Fueled Power Plants: A Case Study on Grindability of Agroforestry Waste Forms. Clean Technol. 2020, 2, 270-289. [CrossRef]

8. Demirbas, A. Potential applications of renewable energy sources, biomass combustion problems in boiler power systems and combustion related environmental issues. Prog. Energy Combust. Sci. 2005, 31, 171-192. [CrossRef]

9. Ferreira Gregorio, V.; Pié, L.; Terceño, A. A systematic literature review of bio, green and circular economy trends in publications in the field of economics and business management. Sustainability 2018, 10, 4232. [CrossRef]

10. Nunes, L.J.R.; Godina, R.; Matias, J.C.d.O. Technological innovation in biomass energy for the sustainable growth of textile industry. Sustainability 2019, 11, 528. [CrossRef]

11. Nunes, L.; Matias, J.; Catalão, J. Economic evaluation and experimental setup of biomass energy as sustainable alternative for textile industry. In Proceedings of the 2013 48th International Universities' Power Engineering Conference (UPEC), Dublin, Ireland, 2-5 September 2013; pp. 1-6.

12. Santini, C.; Cavicchi, A.; Casini, L. Sustainability in the wine industry: Key questions and research trends ${ }^{\text {a }}$. Agric. Food Econ. 2013, 1, 1-14. [CrossRef]

13. Guo, Z.; Yan, N.; Lapkin, A.A. Towards circular economy: Integration of bio-waste into chemical supply chain. Curr. Opin. Chem. Eng. 2019, 26, 148-156. [CrossRef] 
14. Nunes, L.J.; Loureiro, L.M.; Sá, L.C.; Silva, H.F. Evaluation of the potential for energy recovery from olive oil industry waste: Thermochemical conversion technologies as fuel improvement methods. Fuel 2020, 279, 118536. [CrossRef]

15. Maniscalco, M.P.; Volpe, M.; Messineo, A. Hydrothermal carbonization as a valuable tool for energy and environmental applications: A review. Energies 2020, 13, 4098. [CrossRef]

16. Keijer, T.; Bakker, V.; Slootweg, J.C. Circular chemistry to enable a circular economy. Nat. Chem. 2019, 11, 190-195. [CrossRef]

17. Nunes, L.J.; Loureiro, L.M.; Sá, L.C.; Matias, J.C.; Ferraz, A.I.; Rodrigues, A.C. Energy Recovery of Agricultural Residues: Incorporation of Vine Pruning in the Production of Biomass Pellets with ENplus ${ }^{\circledR}$ Certification. Recycling 2021, 6, 28. [CrossRef]

18. Winans, K.; Kendall, A.; Deng, H. The history and current applications of the circular economy concept. Renew. Sustain. Energy Rev. 2017, 68, 825-833. [CrossRef]

19. Nunes, L.J.; Raposo, M.A.; Meireles, C.I.; Pinto Gomes, C.J.; Ribeiro, N.; Almeida, M. Control of Invasive Forest Species through the Creation of a Value Chain: Acacia dealbata Biomass Recovery. Environments 2020, 7, 39. [CrossRef]

20. Nunes, L.J.; Matias, J.C.; Loureiro, L.M.; Sá, L.C.; Silva, H.F.; Rodrigues, A.M.; Causer, T.P.; DeVallance, D.B.; Ciolkosz, D.E. Evaluation of the potential of agricultural waste recovery: Energy densification as a factor for residual biomass logistics optimization. Appl. Sci. 2021, 11, 20. [CrossRef]

21. Fytili, D.; Zabaniotou, A. Circular economy synergistic opportunities of decentralized thermochemical systems for bioenergy and biochar production fueled with agro-industrial wastes with environmental sustainability and social acceptance: A review. Curr. Sustain. Renew. Energy Rep. 2018, 5, 150-155. [CrossRef]

22. Nunes, L.J.R.; Meireles, C.I.R.; Gomes, C.J.P.; de Almeida Ribeiro, N.M.C. Climate Change Impact on Environmental Variability in the Forest; Springer: Cham, Switzerland, 2020.

23. Tag, A.T.; Duman, G.; Ucar, S.; Yanik, J. Effects of feedstock type and pyrolysis temperature on potential applications of biochar. J. Anal. Appl. Pyrolysis 2016, 120, 200-206. [CrossRef]

24. Nunes, L.J. A case study about biomass torrefaction on an industrial scale: Solutions to problems related to self-heating, difficulties in pelletizing, and excessive wear of production equipment. Appl. Sci. 2020, 10, 2546. [CrossRef]

25. Ribeiro, J.M.C.; Godina, R.; Matias, J.C.d.O.; Nunes, L.J.R. Future perspectives of biomass torrefaction: Review of the current state-of-the-art and research development. Sustainability 2018, 10, 2323. [CrossRef]

26. Sá, L.C.; Loureiro, L.M.; Nunes, L.J.; Mendes, A.M. Torrefaction as a pretreatment technology for chlorine elimination from biomass: A case study using Eucalyptus globulus Labill. Resources 2020, 9, 54. [CrossRef]

27. Otero, I.; Boada, M.; Tàbara, J.D. Social-ecological heritage and the conservation of Mediterranean landscapes under global change. A case study in Olzinelles (Catalonia). Land Use Policy 2013, 30, 25-37. [CrossRef]

28. Alves, C.A.; Evtyugina, M.; Cerqueira, M.; Nunes, T.; Duarte, M.; Vicente, E. Volatile organic compounds emitted by the stacks of restaurants. Air Qual. Atmos. Health 2015, 8, 401-412. [CrossRef]

29. Moreira, M.M.; Barroso, M.F.; Porto, J.V.; Ramalhosa, M.J.; Švarc-Gajić, J.; Estevinho, L.; Morais, S.; Delerue-Matos, C. Potential of Portuguese vine shoot wastes as natural resources of bioactive compounds. Sci. Total Environ. 2018, 634, 831-842. [CrossRef]

30. Brito, P.S.; Oliveira, A.S.; Rodrigues, L.F. Energy valorization of solid vines pruning by thermal gasification in a pilot plant. Waste Biomass Valorization 2014, 5, 181-187. [CrossRef]

31. Torreiro, Y.; Pérez, L.; Piñeiro, G.; Pedras, F.; Rodríguez-Abalde, A. The Role of Energy Valuation of Agroforestry Biomass on the Circular Economy. Energies 2020, 13, 2516. [CrossRef]

32. Duca, D.; Toscano, G.; Pizzi, A.; Rossini, G.; Fabrizi, S.; Lucesoli, G.; Servili, A.; Mancini, V.; Romanazzi, G.; Mengarelli, C. Evaluation of the characteristics of vineyard pruning residues for energy applications: Effect of different copper-based treatments. J. Agric. Eng. 2016, 47, 22-27. [CrossRef]

33. Nunes, L.J.; Loureiro, L.M.; Sá, L.C.; Silva, H.F. Waste recovery through thermochemical conversion technologies: A case study with several Portuguese agroforestry by-products. Clean Technol. 2020, 2, 377-391. [CrossRef]

34. Atelge, M.; Atabani, A.; Banu, J.R.; Krisa, D.; Kaya, M.; Eskicioglu, C.; Kumar, G.; Lee, C.; Yildiz, Y.; Unalan, S. A critical review of pretreatment technologies to enhance anaerobic digestion and energy recovery. Fuel 2020, 270, 117494. [CrossRef]

35. Ren, S.; Lei, H.; Wang, L.; Bu, Q.; Chen, S.; Wu, J. Thermal behaviour and kinetic study for woody biomass torrefaction and torrefied biomass pyrolysis by TGA. Biosyst. Eng. 2013, 116, 420-426. [CrossRef]

36. Barzegar, R.; Yozgatligil, A.; Olgun, H.; Atimtay, A.T. TGA and kinetic study of different torrefaction conditions of wood biomass under air and oxy-fuel combustion atmospheres. J. Energy Inst. 2020, 93, 889-898. [CrossRef]

37. Martínez, M.G.; Dupont, C.; Thiéry, S.; Meyer, X.-M.; Gourdon, C. Impact of biomass diversity on torrefaction: Study of solid conversion and volatile species formation through an innovative TGA-GC/MS apparatus. Biomass Bioenergy 2018, 119, 43-53. [CrossRef]

38. Bates, R.B.; Ghoniem, A.F. Biomass torrefaction: Modeling of volatile and solid product evolution kinetics. Bioresour. Technol. 2012, 124, 460-469. [CrossRef]

39. Chen, W.-H.; Peng, J.; Bi, X.T. A state-of-the-art review of biomass torrefaction, densification and applications. Renew. Sustain. Energy Rev. 2015, 44, 847-866. [CrossRef]

40. Zhang, Z.; Duan, H.; Zhang, Y.; Guo, X.; Yu, X.; Zhang, X.; Rahman, M.M.; Cai, J. Investigation of kinetic compensation effect in lignocellulosic biomass torrefaction: Kinetic and thermodynamic analyses. Energy 2020, 207, 118290. [CrossRef]

41. Lu, K.-M.; Lee, W.-J.; Chen, W.-H.; Lin, T.-C. Thermogravimetric analysis and kinetics of co-pyrolysis of raw/torrefied wood and coal blends. Appl. Energy 2013, 105, 57-65. [CrossRef] 
42. Lu, J.-J.; Chen, W.-H. Investigation on the ignition and burnout temperatures of bamboo and sugarcane bagasse by thermogravimetric analysis. Appl. Energy 2015, 160, 49-57. [CrossRef]

43. Yao, Y.; Gao, B.; Zhang, M.; Inyang, M.; Zimmerman, A.R. Effect of biochar amendment on sorption and leaching of nitrate, ammonium, and phosphate in a sandy soil. Chemosphere 2012, 89, 1467-1471. [CrossRef]

44. Uchimiya, M.; Lima, I.M.; Klasson, K.T.; Wartelle, L.H. Contaminant immobilization and nutrient release by biochar soil amendment: Roles of natural organic matter. Chemosphere 2010, 80, 935-940. [CrossRef]

45. Jiang, T.-Y.; Jiang, J.; Xu, R.-K.; Li, Z. Adsorption of $\mathrm{Pb}$ (II) on variable charge soils amended with rice-straw derived biochar. Chemosphere 2012, 89, 249-256. [CrossRef]

46. Chen, D.; Gao, A.; Cen, K.; Zhang, J.; Cao, X.; Ma, Z. Investigation of biomass torrefaction based on three major components: Hemicellulose, cellulose, and lignin. Energy Convers. Manag. 2018, 169, 228-237. [CrossRef]

47. Zhang, Z.; Zhao, Y.; Wang, T. Spirulina hydrothermal carbonization: Effect on hydrochar properties and sulfur transformation. Bioresour. Technol. 2020, 306, 123148. [CrossRef]

48. Wang, T.; Zhai, Y.; Zhu, Y.; Li, C.; Zeng, G. A review of the hydrothermal carbonization of biomass waste for hydrochar formation: Process conditions, fundamentals, and physicochemical properties. Renew. Sustain. Energy Rev. 2018, 90, 223-247. [CrossRef]

49. Chen, Y.-C.; Chen, W.-H.; Lin, B.-J.; Chang, J.-S.; Ong, H.C. Fuel property variation of biomass undergoing torrefaction. Energy Procedia 2017, 105, 108-112. [CrossRef]

50. Piskorz, J.; Radlein, D.; Scott, D.S. On the mechanism of the rapid pyrolysis of cellulose. J. Anal. Appl. Pyrolysis 1986, 9, 121-137. [CrossRef]

51. Antal, M.J.J.; Varhegyi, G. Cellulose pyrolysis kinetics: The current state of knowledge. Ind. Eng. Chem. Res. 1995, 34, 703-717. [CrossRef]

52. Chan, K.Y.; Van Zwieten, L.; Meszaros, I.; Downie, A.; Joseph, S. Agronomic values of greenwaste biochar as a soil amendment. Soil Res. 2008, 45, 629-634. [CrossRef]

53. Singh, B.; Singh, B.P.; Cowie, A.L. Characterisation and evaluation of biochars for their application as a soil amendment. Soil Res. 2010, 48, 516-525. [CrossRef]

54. Woolf, D.; Amonette, J.E.; Street-Perrott, F.A.; Lehmann, J.; Joseph, S. Sustainable biochar to mitigate global climate change. Nat. Commun. 2010, 1, 1-9. [CrossRef] [PubMed]

55. Glaser, B.; Parr, M.; Braun, C.; Kopolo, G. Biochar is carbon negative. Nat. Geosci. 2009, 2, 2. [CrossRef]

56. Arias, B.; Pevida, C.; Fermoso, J.; Plaza, M.; Rubiera, F.; Pis, J. Influence of torrefaction on the grindability and reactivity of woody biomass. Fuel Process. Technol. 2008, 89, 169-175. [CrossRef]

57. Simonic, M.; Goricanec, D.; Urbancl, D. Impact of torrefaction on biomass properties depending on temperature and operation time. Sci. Total Environ. 2020, 740, 140086. [CrossRef]

58. Monedero, E.; Portero, H.; Lapuerta, M. Pellet blends of poplar and pine sawdust: Effects of material composition, additive, moisture content and compression die on pellet quality. Fuel Process. Technol. 2015, 132, 15-23. [CrossRef]

59. Nielsen, H.P.; Frandsen, F.; Dam-Johansen, K.; Baxter, L. The implications of chlorine-associated corrosion on the operation of biomass-fired boilers. Prog. Energy Combust. Sci. 2000, 26, 283-298. [CrossRef]

60. Lith, S.C.v.; Frandsen, F.J.; Montgomery, M.; Vilhelmsen, T.; Jensen, S.A. Lab-scale investigation of deposit-induced chlorine corrosion of superheater materials under simulated biomass-firing conditions. Part 1: Exposure at 560 ${ }^{\circ} \mathrm{C}$. Energy Fuels 2009, 23 , 3457-3468. [CrossRef]

61. San José, M.J.; Alvarez, S.; García, I.; Peñas, F.J. A novel conical combustor for thermal exploitation of vineyard pruning wastes. Fuel 2013, 110, 178-184. [CrossRef]

62. Bilandzija, N. Energy potential of fruit tree pruned biomass in Croatia. Span. J. Agric. Res. 2012, $292-298$.

63. Sun, X.; Wei, X.; Zhang, J.; Ge, Q.; Liang, Y.; Ju, Y.; Zhang, A.; Ma, T.; Fang, Y. Biomass estimation and physicochemical characterization of winter vine prunings in the Chinese and global grape and wine industries. Waste Manag. 2020, 104, 119-129. [CrossRef]

64. Acquadro, S.; Appleton, S.; Marengo, A.; Bicchi, C.; Sgorbini, B.; Mandrone, M.; Gai, F.; Peiretti, P.G.; Cagliero, C.; Rubiolo, P. Grapevine green pruning residues as a promising and sustainable source of bioactive phenolic compounds. Molecules 2020, 25,464 . [CrossRef]

65. Loupit, G.; Prigent, S.; Franc, C.; De Revel, G.; Richard, T.; Cookson, S.J.; Fonayet, J.V. Polyphenol profiles of just pruned grapevine canes from wild Vitis accessions and Vitis vinifera cultivars. J. Agric. Food Chem. 2020, 68, 13397-13407. [CrossRef]

66. Allesina, G.; Pedrazzi, S.; Puglia, M.; Morselli, N.; Allegretti, F.; Tartarini, P. Gasification and wine industry: Report on the use vine pruning as fuel in small-scale gasifiers. In Proceedings of the European Biomass Conference and Exhibition, Copenhagen, Denmark, 14-18 May 2018; pp. 722-725.

67. Margaritis, N.; Grammelis, P.; Karampinis, E.; Kanaveli, I.-P. Impact of torrefaction on vine Pruning's fuel characteristics. J. Energy Eng. 2020, 146, 04020006. [CrossRef]

68. Azuara, M.; Sáiz, E.; Manso, J.A.; García-Ramos, F.J.; Manyà, J.J. Study on the effects of using a carbon dioxide atmosphere on the properties of vine shoots-derived biochar. J. Anal. Appl. Pyrolysis 2017, 124, 719-725. [CrossRef]

69. Dunnigan, L.; Morton, B.J.; Ashman, P.J.; Zhang, X.; Kwong, C.W. Emission characteristics of a pyrolysis-combustion system for the co-production of biochar and bioenergy from agricultural wastes. Waste Manag. 2018, 77, 59-66. [CrossRef] 
70. Hoffmann, V.; Jung, D.; Zimmermann, J.; Rodriguez Correa, C.; Elleuch, A.; Halouani, K.; Kruse, A. Conductive carbon materials from the hydrothermal carbonization of vineyard residues for the application in electrochemical double-layer capacitors (EDLCs) and direct carbon fuel cells (DCFCs). Materials 2019, 12, 1703. [CrossRef]

71. Kraiem, N.; Lajili, M.; Limousy, L.; Said, R.; Jeguirim, M. Energy recovery from Tunisian agri-food wastes: Evaluation of combustion performance and emissions characteristics of green pellets prepared from tomato residues and grape marc. Energy 2016, 107, 409-418. [CrossRef]

72. Picchi, G.; Silvestri, S.; Cristoforetti, A. Vineyard residues as a fuel for domestic boilers in Trento Province (Italy): Comparison to wood chips and means of polluting emissions control. Fuel 2013, 113, 43-49. [CrossRef]

73. García, R.; Pizarro, C.; Álvarez, A.; Lavín, A.G.; Bueno, J.L. Study of biomass combustion wastes. Fuel 2015, 148, 152-159. [CrossRef] 